LWSA

Local Wisdom, Social, and Arts

PAPER - OPEN ACCESS

\title{
Gambaran Optimisme pada Suami yang Mengalami Disabilitas
}

\author{
Author \\ : Margaretha Novitasari \\ DOI \\ : 10.32734/lwsa.v1i1.172 \\ Electronic ISSN \\ : 2654-7058 \\ Print ISSN \\ : 2654-7066 \\ Volume 1 Issue 1 - 2018 TALENTA Conference Series: Local Wisdom, Social and Arts
}

\section{(c) $(1) \Theta$}

This work is licensed under a Creative Commons Attribution-NoDerivatives 4.0 International License.

Published under licence by TALENTA Publisher, Universitas Sumatera Utara
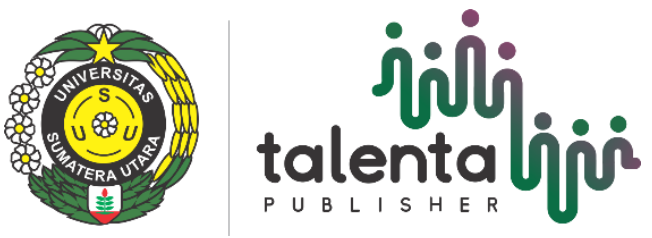


\title{
ن talenta i̊ji̊ TALENTA Conference Series \\ Available online at https://talentaconfseries.usu.ac.id

\section{Gambaran Optimisme pada Suami yang Mengalami Disabilitas}

\author{
Margaretha Novitasari ${ }^{\mathrm{a}}$, Rahma Fauzia ${ }^{\mathrm{b}}$ \\ ${ }^{a}$ Fakultas Psikologi, Universitas Sumatera Utara, Medan 20155 \\ ${ }^{b}$ Departemen Psikologi Klinis, Universitas Sumatera Utara, Medan 20155 \\ rfsinulingga@gmail.com
}

\begin{abstract}
Optimis memerupakan keyakinan bahwa akan lebih banyak hal baik yang terjadi dari pada hal yang buruk (Carr, 2004). Individu yang optimis akan berusaha untuk mencapai tujuan meskipun mengalami kesulitan (Carver \& Scheier, 2001). Pada suami yang mengalami disabilitas, mereka harus menghadapi perubahan fisik yang diakibatkankarena kecelakaan ataupun penyakit. Optimisme dapat mempengaruhi bagaimana individu memandang keterbatasannya saat ini. Penelitian ini bertujuan untuk melihat gambaran optimisme suami yang mengalami disabilitas.

Subjek dalam penelitian ini berjumlah 15 orang dengan teknik pengambilan sampel insidental. Penelitian ini menggunakanskalaLOT-R(LifeOrientationTest-Revised) dikembangkan oleh Carver dan Scheier berdasarkan pandangan mereka tentang optimisme. Skala ini terdiri dari 10 aitem yang terdiri dari 6 aitem yang diukur dan 4 aitem filler. Alat ukur yang digunakan memiliki reabilitas 0,675 . Hasil penelitian menunjukkan bahwa suami yang mengalami disabilitas lebih banyak yang optimis dibandingkan denganyang tidakterkategori (ambivalen). Dari 15 orang, 13 orang optimis dan 2 orang tidak terkategori.Hal ini mengindikasikan bahwa meskipun mengalami disabilitas, mereka tetap memiliki keyakinan untuk menghadapi kondisi tersebut।
\end{abstract}

Kata Kunci: suami, disabilitas,optimisme

\section{Pendahuluan}

Menurut pandangan tradisional, peran utama laki-laki adalah sebagai penguasa utama rumah tangga yang memiliki hak-hak istimewa dan otoritas terbesar dalam keluarga dan anggota keluarga yang lain harus tunduk kepadanya. Lakilaki dalam posisinya sebagai suami dan ayah merupakan figur sentral dalam keluarga (Kusujiarti dalam Supriyantini, 2002). Peran sebagai kepala keluarga ini menuntut laki- laki untuk memiliki kondisi fisik dan psikologis yang baik, namun tidak semua kepala keluarga memiliki kondisi fisik dan psikologis yang baik. Padabeberapakeluarga,kepalakeluarga yang mengalami disabilitas menyebabkan keterbatasan dalam menjalankan perannya sebagai kepala keluarga. Selain harus menyesuaikan diri dengan keterbatasan yang dialami, suamijuga umumnya akan mengalami beberapa perubahan berkaitan dengan perannya sebagai kepala keluarga. Kurangnya lapangan pekerjaan bagi penyandang disabilitas menyebabkan mereka mengalami kesulitan untuk mendapatkan penghasilan sendiri. Hal ini didukung dengan hasil Survei Sosial Ekonomi Nasional tahun 2002, dari 20 juta penyandang disabilitas di Indonesia, sekitar 80 persennya tidak memiliki pekerjaan.

Disabilitas yang dialami membuat individu cenderung merasa dirinya tidak berdaya, kurang percaya diri, rendah diri, sensitif, cemas, dan sering kali merasa takut dirinya akan menjadi beban bagi orang lain (Carolina dalam Suparni, 2009). Hal ini juga dipengaruhi oleh sikap dan pandangan negatif lingkungan, yang pada umumnya menganggap orang yang disabilitas sebagai orang yang tidak mampu dalam kehidupan sosial. 
Perubahan yang dialami ini akan menjadi sumber stres bagi individu. Stres merupakan kondis iketika interaksi individu dengan lingkungan mengarahkan individu berpandangan bahwa ada

ketidaksesuaian antara tuntutan fisik dan psikologis terhadap situasi dan sumber biologis, psikologis dan sistem sosial sosial (Sarafino \& Smith, 2011). Untuk menghadapi kondisi ini penting bagi individu untuk dapat melakukan coping. Carr (2004) menyatakan individu yang optimis akan melakukan coping untuk dapat mencapai tujuan yang diinginkan.

Carver dan Scheier (2001) mengembangkan teori expectancy-value model. Menurut teori ini individu yang optimis akan memiliki harapan lebih banyak hal baik (positif) yang terjadi dimasa depan. Optimis memerupakan expectancy (ekspektasi) bahwa akan lebih banyak hal baik yang terjadi dar ipadahal buruk dimasa depan (Carr, 2004).

Keuntungan optimis menurut Ginnis (dalam Kasmayati, 2013) antara lain hidup lebih bertahan lama, kesehatan lebih baik, menggunakan waktu lebih bersemangat dan berenergi, berusaha keras mencapai tujuan, lebih berprestasi dalam potensinya, mengerjakan sesuatu jadi lebih baik seperti dalam hubungan sosial, pendidikan,pekerjaan dan olahraga.Jika dikaitkan pada suami yang mengalami disabilitas maka diharapkan suami optimisakan lebih mampu menyesuaikan diri dengan kondisinya. Dibidang kesehatan selain mampu meningkatkan kesehatan tubuh dan sistem kekebalan,optimisme juga dapat mengurangi depresi.Selain itu dampak lain stres seperti rasa takut, kecemasan dan marah (Sarafino \& Smith, 2011) juga lebih sedikit dibandingkan individu pesimis.

\section{Optimisme}

Menurut Carver dan Scheier (2001) optimis merupakan individu yang memperkirakan hal baik yang terjadi pada dirinya, sedangkan pesimis adalah individu yang memperkirakan dirinya akan mengalami hal buruk. Optimisme merupakan expectancy (ekspektasi) bahwa akan lebih banyak hal baik yang terjadi daripada hal buruk di masa depan (Carr, 2004). Individu optimis saat menghadapi kesulitan akan terus berusaha mencapai tujuan dan akan menyesuaikan diri dengan situasi yang dihadapi dengan menggunakan strategi coping yang efektif untuk mencapai tujuan yang diinginkan. Individu yang optimis dan pesimis, berbeda caranya dalam mengatasi masalah dan menghadapi tantangan, cara dan hasil yang diperoleh dalam menyelesaikan kesulitan yang dihadapi (Carver \& Scheier, 2004). Optimis ketika menghadapi tantangan akan menghadapinya dengan percaya diri dan gigih, meskipun kemajuan dalam menyelesaikan tantangan tersebut lambat karena mereka percaya kesulitan dapat ditangani. Berbeda dengan optimis, pesimis cenderung akan menyerah ketika menghadapi kondisi yang sulit dan menantang, selain itu mereka juga cenderung memiliki perasaan negatif dan membayangkan kalau suatu kejadian yang buruk akan terjadi (Carver \& Scheier, 2001).

\subsection{Optimisme dan Expectancy Value Model}

Konsep optimisme berkaitan dengan teori motivasi atau yang lebih dikenal dengan teori expectancy-value (Carver \& Scheier, 2001). Teori ini berpandangan bahwa perilaku individu disusun oleh dua aspek: (1) goal (tujuan) yang merupakan state atau tindakan yang dianggap diinginkan atau tidak diinginkan. Individu mencoba untuk menyesuaikan perilaku sesuai dengan yang dia inginkan dan menjauhkan diri dari apa yang tidak diinginkan. Semakin penting tujuan tersebut bagi seseorang, semakin besar nilainya dalam memberi motivasi pada individu. Tanpa memiliki tujuan, seseorang tidak memiliki alasan untuk bertindak; (2) expectancy (ekspektasi) yang merupakan confidence (kepercayaan) ataupun doubt (keraguraguan) dalam pencapaian tujuan. Jika individu ragu-ragu, tidak akan ada tindakan. Keraguan dapat mengganggu usaha untuk mencapai tujuan baik sebelum tindakan dimulai atau saat sedang berlangsung. Hanya individu dengan ekspektasi yang cukup yang mampu melanjutkan usahanya.

\subsection{Optimisme dan Expectancy Value Model}

Berdasarkan beberapa penelitian yang dilakukan terhadap optimisme, disimpulkan bahwa optimisme sangat membantu individu dalam berbagai bidang. Optimis akan lebih cepat menerima kenyataan akan kondisi yang dihadapinya sekarang dibandingkan dengan individu yang pesimis (Carver \& Scheier, 2004). Optimisme berkaitan dengan kondisi kesehatan yang lebih baik. Individu dengan optimis yang rendah lebih membutuhkan psikoterapi dibandingkan dengan individu dengan optimisme yang tinggi (Karlsson, 2011). 
Ketika individu memiliki ekspektasi, maka individu akan mampu mengatasi kesulitan yang dihadapinya dan mencari penyelesaian dari masalah tersebut meskipun sulit (Carver \& Scheier, 2001). Individu yang memiliki kepercayaan tentang masa depan akan terus mengeluarkan usaha walaupun menghadapi masa sulit, sedangkan individu yang ragu akan berhenti mengeluarkan usahanya.

\section{Optimisme}

\subsection{Partisipan}

Partisipan dalam penelitian ini berjumlah 15 orang suami yang mengalami disabilitas. Partisipan ini diambil menggunakan teknik incidental. Partisipan yang terlibat dalam penelitian ini memiliki karakteristik: (1) laki-laki; (2) sudah menikah; ( 3) memiliki disabilitas fisik, penglihatan, atau pendengaran.

\subsection{Prosedur dan Alat Ukur}

Pengumpulan data dilakukan dengan mendatangi langsung partisipan dan meminta kesediaan partisipan untuk mengisi skala. Peneliti membacakan langsung skala pada partisipan dan partisipan hanya tinggal memberikan respon atau jawaban dari pertanyaan yang dibacakan peneliti.

Penelitian ini menggunakan skala LOT-R (Life Orientation Test-Revised) yang dikembangkan oleh Carver dan Scheier. LOT-R berbentuk Likert dengan 10 aitem (4 aitem filler dan 6 aitem yang diukur), menggunakan 5 pilihan respon (unfavourable dari $0=$ sangat tidak setuju, $1=$ tidak setuju, $2=$ netral, $3=$ setuju $4=$ sangat setuju dan favourable dari $0=$ sangat setuju, $1=$ setuju, $2=$ netral, $3=$ tidaksetuju $4=$ sangat tidak setuju).

Peneliti menggunakan LOT-R yang telah ditranslasi pada penelitian skripsi yang berjudul Hubungan antara Social Support dengan Optimisme pada Orang dengan HIV/AIDS (ODHA), yang disusun oleh Erni Julianti Simanjuntak. Reabilitas skala LOT-Rini0,675. Validitas alat ukur tidak diuji kembali oleh peneliti. Untuk keperluan skoring,digunakan pengukuran denganpertimbanganstandareror sebagai tolak ukur optimisme $(X \pm 2,26)$. Dikatakan optimis jika rerata skornya diatas rentang pertimbangan standar eror $(X+2,26)$,pesimisjika rerata skor beradadi bawahrentang pertimbangan standar eror $(\mathrm{X}-2,26)$,dan ambivalen jika berada antara rer atas korpesimis dan optimis $(X-2,26 \leqslant X \leqslant X+2,26)$.

\section{Hasil}

Partisipan dalam penelitian ini berjumlah 15 orang, dimana yang paling banyak beradapadakelompok usiadewasamadyaada11orang (73,33\%), sedangkan yang berada dalam kelompok dewasa awal sebanyak 4 orang (26,67\%).Partisipan dalam penelitian ini paling banyak mengalami disabilitas fisik yaitu sebanyak 13 orang $(86,67 \%)$. Sisanya 2 orang $(13,33 \%)$ mengalami disabilitas penglihatan.

Partisipan lebih banyak mengalami keterbatasan fisik karena penyakit 60\% (9orang) dibandingkan dengan yang disabilitas karena kecelakaan 40\% (6 orang). Partisipan dalam penelitian ini paling banyak mengalami disabilitas antara 4 sampai 32 bulan yaitu sebanyak 7 orang (46,67\%), dan yang paling sedikit adalah antara 120 hingga 148 bulan yaitu 4 orang $(26,67 \%)$.

Kebanyakan partisipan mengalami disabilitas sesudah pernikahan yaitu 13 orang $(86,67 \%)$, sedangkan sebelum pernikahan hanya 2 orang saja (13,33\%). Sebelum mengalami disabilitas, keseluruhan partisipan bekerja (100\%), sesudah mengalami kondisi disabilitas, partisipan yang tidak bekerja menjadi 9 orang $(60 \%)$.

Sebelum mengalami disabilitas, istri partisipan yang bekerja ada 9 orang $(60 \%)$ sedangkan yang tidak bekerja ada 6 orang $(40 \%)$. Sesudah mengalami disabilitas istri partisipan yang bekerja menjadi lebih banyak yaitu11orang $(73,33 \%)$ sedangkan istri partisipan yang tidak bekerja jadi tinggal 4 orang $(26.67 \%)$.

Peran utama kepala keluarga menurut pendapat 11 orang partisipan adalah untuk menafkahi keluarga (80\%), sedangkan yang 3orang(20\%) menganggap peran utama kepala keluarga bukan menafkahi keluarga. Masing-masing dari 3 orang partisipan tersebut menganggap peran utama kepala keluarga adalah untuk membahagiakan keluarga, melindungi keluarga dan mendidik anak. 
Jumlah partisipan yang memiliki ekspektasi untuk cepat sembuh di awal mengalami disabilitas yang paling banyak yaitu10 orang $(66,67 \%)$, sedangkan yang berharap masih bisa bekerja 4 orang $(26,67 \%)$ dan yang satu orang lagi $(6,67 \%)$ tidak memiliki ekspektasi apapun.

Kebanyakan partisipan saat ini memiliki ekspektasi untuk sembuh yaitu sebanyak 10 orang $(66,67 \%)$. Tiga orang partisipan(20\%) berharap bisa kembali normal. Satu orang $(6,67 \%)$ hanya berharap ada keajaiban yang bisa menyembuhkan penyakitnya dan 1 orang subjek $(6,67 \%)$ tidak memiliki harapan apapun terhadap kondisi fisiknya saat ini.

Selama mengalami disabilitas, 1 orang partisipan $(6,67 \%)$ tidak pernah mengikuti pengobatan apapun. Satu orang partisipan $(6,67 \%)$ hanya mengikuti pengobatan medis dan 6 orang partisipan (40\%) hanya mengikuti pengobatan non medis saja. Sebanyak 7 orang partisipan(46,67\%)mencoba dua pengobatan baik medis maupun non medis untuk mencari kesembuhan.

Table 1. Gambaran Umum Partisipan.

\begin{tabular}{|c|c|c|}
\hline Faktor Sosiodemografi & Frekuensi & Persentase $(\%)$ \\
\hline \multicolumn{3}{|l|}{ 1..Usia: } \\
\hline a. Dewasa awal (17-40tahun) & 4 & 26,67 \\
\hline b. Dewasa madya (41-64tahun) & 11 & 73,33 \\
\hline \multicolumn{3}{|l|}{ 2. Disabilitas yang Dialami: } \\
\hline a.Fisik & 13 & 86,67 \\
\hline b. Penglihatan & 2 & 13,33 \\
\hline \multicolumn{3}{|l|}{ 3. Penyebab disabilitas: } \\
\hline a. Penyakit & 9 & 60 \\
\hline b. Kecelakaan & 6 & 40 \\
\hline \multicolumn{3}{|l|}{ 4. Durasi Disabilitas: } \\
\hline a. 4-32 bulan & 7 & 46,67 \\
\hline b. $33-61$ bulan & 1 & 6,67 \\
\hline c. $62-90$ bulan & 2 & 13,33 \\
\hline d. $91-119$ bulan & 1 & 6,67 \\
\hline e. $120-148$ bulan & 4 & 26,67 \\
\hline \multicolumn{3}{|l|}{ 5. Subjek Mengalami Disabilitas: } \\
\hline a. Sebelum Menikah & 2 & 13,33 \\
\hline b. Sesudah Menikah & 13 & 86,67 \\
\hline \multicolumn{3}{|l|}{ 6. Subjek Sebelum Disabilitas: } \\
\hline a. Bekerja & 15 & 100 \\
\hline b. Tidak Bekerja & 0 & 0 \\
\hline \multicolumn{3}{|l|}{ 7. Subjek sesudah Disabilitas: } \\
\hline a. Bekerja & 6 & 40 \\
\hline b. Tidak Bekerja & 9 & 60 \\
\hline \multicolumn{3}{|l|}{ 8. IstriSubjekSebelumDisabilitas } \\
\hline a. Bekerja & 9 & 60 \\
\hline b. TidakBekerja & 6 & 40 \\
\hline \multicolumn{3}{|l|}{ 9. Istri Subjek Sesudah Disabilitas: } \\
\hline a. Bekerja & 11 & 73,33 \\
\hline b. TidakBekerja & 4 & 26,67 \\
\hline
\end{tabular}


Peran Kepala Keluarga:
a. Menafkahi Keluarga
12
80
b. Membahagiakan Keluarga
6,67
c. Melindungi Keluarga
1
6,67
d. Mendidik Anak
1
1
6,67
11. Ekspektansi Diawal Mengalami Disabilitas:
a. Cepat Sembuh
10
66,67
b. Masih bisa bekerja
4
26,67
c. Tidak ada
1
12. Ekspektansi Sekarang:
a. Cepat Sembuh
10
6,67
b. Bisa kembali normal
320
c. Ada mukjizat yang bisa Menyembuhkan

$1 \quad 6,67$
d. Tidak berharap apa-apa
13. Pengobatan yang Di ikuti:
a. Medis
b. Non Medis
$1 \quad 6,67$
c. Medis dan NonMedis
$6 \quad 40$
d. Tidak ada
7
46,67
1
66,67
6,67
6,6

Hasil penelitian menunjukkan bahwa partisipan kebanyakan optimis (86,67\%), duapartisipan tidak terkategori atau ambivalen $(13,33 \%)$ dan tidak adapartisipanyang pesimis. Dua partisipan yang ambivalen belum dapat masuk kategori optimis namun juga tidak bisa dikategorikan pesimis.Tabel 2 menunjukkan partisipan dikategorikan ke dalam 3 kelompok berdasarkan total skor LOT-R yang diperoleh. Partisipan dikatakan pesimis ketika total skor partisipan lebih kecil dari 9,74. Partisipan dikatakan tidak terkategori ketika memiliki total skor antara 9,74 sampai 14,26. Partisipan dikatakan optimis ketika total skor yang diperolehnya melebihi 14,26.

Table 2. Kategori Optimisme

\begin{tabular}{llcc}
\hline Kategori & Rentang Skor & Frekuensi & Persentase $(\%)$ \\
\hline Pesimis & $<9,74$ & 0 & 0 \\
Tidakterkategori & $9,74-14,26$ & 2 & 13,33 \\
Optimis & $<14,26$ & 13 & 86,67 \\
\hline
\end{tabular}

\section{Kesimpulan}

Hasil penelitian menunjukkan sebagian besar suamiyang terlibat dalam penelitian tergolong optimis. Individu yang optimis memiliki pandanganakan lebih banyak hal baik yang akan terjadi dimasa depan (Carr,2004). Suami yang optimis memiliki keyakinanakan lebih banyak hal baik yang akan dialaminya meskipun berada dalam kondisi disabilitas.

Berdasarkan beberapa penelitian yang dilakukan terhadap optimisme, disimpulkan bahwa optimisme sangat membantu individu dalam berbagai bidang. Optimisakan lebih cepat menerima kenyataan akan kondisi yang dihadapinya sekarang dibandingkan dengan individu yang pesimis (Carver \& Scheier, 2004). Optimisme juga berkaitan dengan kondisi kesehatan yang lebih baik. Individu dengan optimis yang rendah lebih membutuhkan psikoterapi dibandingkan dengan individu dengan optimisme yang tinggi (Karlsson, 2011).

Optimisme berkaitan dengan strategi coping (Carr, 2004) .Optimisme diharapkan menjadi cara untuk melindungi individu dari kondisi stres. Pesimis akan lebih stres terhadap kondisinya (Carver \& Scheier, 2001) dibandingkan 
dengan mereka yang optimis. Pada suami yang mengalami disabilitas optimisme, diharapkan mampu melindungi mereka dari stres akibat perubahan fisik yang dialami.

Faktor sosiodemografis, seperti: usia, jenis disabilitas yang dialami, penyebab disabilitas, durasi disabilitas,disabilitas sebelum/sesudahmenikah,bekerja/tidaknyasuami,bekerja/tidaknya istri, pandangan akan peran kepala keluarga, ekspektasi akan kondisi dan pengobatan yang diikuti ternyata belum tentu berkaitan dengan optimisme. Lamanya disabilitas ternyata tidak menunjukkan kalau individu yang telah lama mengalaminya akan optimis dan yang baru mengalaminya akan pesimis atau sebaliknya. Suami yang disabilitas lebih antara 120-148 bulan ternyata ada yang optimis namun ada juga yang tidak terkategori. Mereka yang disabilitas dari 4-32 bulan malahan masuk dalam kategori optimis.

Penelitihanya mendapat kesimpulan bahwa suami yang disabilitas banyak yang optimis namun tidak tahu faktor apa yangmenyebabkan mereka optimis untuk itu pada peneliti ataupun pihak-pihak yang tertarik untuk meneliti fenomena optimisme pada suami disabilitas sebaiknya menggunakan metode kualitatif untuk dapat melihat bagaimana dinamika optimisme pada suami disabilitas, melihatt ernyata dari penelitian ini meskipun banyak faktor yang diperkirakan dapat mempengaruhi optimisme, namun tidak terlihat bagaimana sebenarnya dinamika yang menyebabkan suami disabilitas bisa optimis.

Faktor yang ada pada penelitian ini dapat menjadi faktor yang digali lebih dalam lagi pada penelitian selanjutnya. Peneliti selanjutnya yang tertarik untuk menggunakan alat ukur LOT-R seperti yang digunakan dalam penelitian ini sebaiknya menggunakan jumlah sampel penelitian yang lebih besar dan data sosiodemografis yang lebih banyak sehingga datayang diperoleh lebih lengkapdan meningkatkan reabilitas dari alat ukur.

Aitem atau butir soal sebaiknya diperbanyak dan disesuaikan dengan budaya atau adat Indonesia. Aitem-aitem tersebut juga dapat dimodifikasi dan dikaitkan langsung dengan objek penelitian sehingga hasil yang diperoleh bukan hanya gambaran optimisme secara umum.

Melihat pentingnya optimisme pada suami disabilitas, diharapkan adanya peran serta dari keluarga dan orang-orang terdekat untuk membantu proses adaptasi pada mereka yang mengalami kondisi ini. Keluarga juga diharapkan tidak putus asa untuk mencoba berbagai pengobatan yang mungkin dapat memberikan kesembuhan pada mereka yang mengalami kondisi disabilitas.

Melihat banyaknya tantangan yang akan dihadapi oleh mereka yang mengalami disabilitas diharapkan pada psikolog yang memiliki klien dengan kondisi ini dapat memberikan konseling untuk mengkonstruksi ulang tujuan yang akan dicapainya dengan keterbatasan yang dimiliki, dengan begitu individuakan lebih bisa menerima kondisinya yang baru.

\section{References}

[1] Carr,A.(2004).PositivePsychology:TheScienceofHappinessandHumanStrengths.New York: Brunner- Routledge.

[2] Carver,C.S.,\&Scheier,M.F.(2001). Optimism,Pessimism, and Self-Regulation.InE.C. Chang, Optimism \& pessimism: Implications for theory, research, and practice (pp.31-51).Washington,DC:American Psychological Association.

[3] Carver,C.S., \& Scheier,M.F.(2002). Optimism.InC.Synder, \& S.J.Lopez,Handbookof Positive Psychology (pp.231-243). NewYork: Oxford University Press.

[4] Carver,C.S.,\&Scheier,M.F.(2004).Optimism.In C.Snyder,\&S.J. Lopez,Positive Psychology Assessment: A Handbook of Model and Measure s(pp.75-89). Washington, DC: American Psychological Association.

[5] De Genova,M.K.(2008).Intimate Relationship, Marriages, and Families (7thedition). New york: McGraw-Hill.

[6] Julianty, E. (2011). Hubungan antara Social Support dengan Optimismepada Orang dengan HIV/AIDS(ODHA).

[7] Kasmayati (2013).Optimisme Remaja Penyandang Disabilitas Akibat Kecelakaan.

[8] Karlsson,H.,etal.(2011).LowLevelofOptimismPredictsInitiationofPsychotheraphyfor Depression: Results from the Finnish Public Sector Study . 238-244.

[9] Papalia,D.P.,Olds,S.W., \& Feldman,R.D.(2007) .Human Development (10thEdition). New York: McGraw Hill. Sarafino,E.P., \& Smith, T.W.(2011).Health Psychology.USA: John Wiley \& Sons,Inc.

[10] Singh,Y.K.(2006).Fundamental of Research Methodology and Statistics.New Delhi: New AgeInternational (P)Limited Publishers

[11] Suparni, S. (2009).Kemampuan Berafiliasi pada Remaja Tuna Rungu.

[12] Supriyantini, S. (2002). Hubungan antara Pandangan Peran Gender dengan Keterlibatan Suami dalam Kegiatan Rumah Tangga. Medan: USU Digital Library.

[13] Widyarini, M. (2009). Membangun Hubungan antar Manusia. Tanggal akses 5 Mei 2013. 